\title{
The Role of U.S. Elite Military Schools in Promoting Intercultural Understanding and Democratic Governance
}

\author{
Carol Atkinson \\ University of Southern California
}

\begin{abstract}
Educational exchanges at the U.S. military's war and staff colleges promote intercultural understanding, international security, and help the United States achieve its foreign policy goals. This article provides an overview of the different types of U.S. military education and training programs that are open to foreign participation, and explores the differences between these and civilian exchange programs. It looks at the impacts of military educational exchange programs on their participants, and also draws lessons learned for the design and administration of exchange programs.
\end{abstract}

Keywords: Education, military, soft power, exchange, IMET, socialization, constructivism

\section{Introduction}

Educational exchanges are often thought of as a formative experience in the life of a young college student who decides to spend a semester aboard or the mid-career adventure of a senior academic scholar who participates in one of the many Fulbright exchange programs. However, these are not the only types of exchange programs, nor are they the most influential in terms of policy impact. This article argues that some of the most influential international exchange programs are hosted by the U.S. military's elite schools, its war and staff colleges. These military exchange programs are structured to build trust, intercultural understanding, and a shared frame of reference amongst U.S. military officers and their international counterparts. The result is a worldwide epistemic community of U.S. educated military officers.

U.S.-hosted military educational exchange programs are extensive and the professional networks that are built at these schools have had important impacts on their participants and, more generally, on international institutions and international security. This is especially true for the exchange participants at the United States' elite professional military schools, the war and staff colleges. These schools host mid-level to senior-level military officers and defenserelated civilians from around the world. The majority of these exchange participants are the rising elite in their home countries and they are likely to hold high ranking military positions in the future. Indeed, substantial portion of international graduates of U.S. war and staff colleges have become chief of their defense establishment or the commander of multinational forces. U.S. military exchange programs engage those leaders who have a real chance of instituting reforms and bringing change to their home countries. The military educational exchanges build cooperative relationships that have been shown to help maintain regional

Carol Atkinson, Professor of the Practice of International Relations, University of Southern California. Email: carol.atkinson@ alumni.duke.edu. 
peace and stability, and the exchanges are also explicitly tasked with supporting democratic institutions, values and norms.

This article describes how the exchanges at the U.S. military's war and staff colleges are structured to achieve their goals and assesses the lessons that can be learned from them. The article begins with an overview of the different types of U.S. military education and training programs that are open to foreign participation and then places the educational exchange programs at the U.S. military's war and staff colleges within this overall context. The nature of the military exchange experience for the participants, both U.S. and foreign, is described to include the overall program structure, the curriculum taught, and extracurricular activities. The educational experience at U.S. war and staff colleges is quite different from civilian exchange programs such as the Fulbright Scholar Program or as experienced by foreign exchange students at U.S. universities. These differences are on many levels from how the classroom is organized to the extensive amount of social interaction and experiential learning that is planned outside of the classroom by the military schools. The article examines several important impacts of the military exchanges on their international participants and includes lessons that can be applied to the design and administration of international educational exchange programs more broadly.

\section{U.S. Military Educational Exchanges}

There are a number of U.S. security cooperation programs that provide military education and training to foreign personnel, both soldiers and government civilians. Taken all together, the U.S. Department of Defense provides education and training to more than 55,000 foreign personnel each year. ${ }^{1}$ The U.S. government program called International Military Education and Training (IMET) is its centerpiece exchange program; the U.S. Congress funds it, the Department of State manages the funding, and the Department of Defense designs and implements the curriculum. The U.S. Congress established it in the International Security Assistance and Arms Export Control Act of 1976. Today IMET education and training courses are quite extensive; on an annual basis the U.S. government provides grant funding for foreign participation in more than 4,000 formal courses at approximately 150 U.S. and NATO military schools and installations. ${ }^{2}$ As directed by the U.S. Congress through the Department of State and the Department of Defense the official goals of the program are to:
1. Further the goal of regional stability through effective, mutually beneficial military-to- military relations that culminate in increased understanding and defense cooperation between the United States and foreign countries;
2. Provide training that augments the capabilities of participant nations' military forces to support combined operations and interoperability with U.S. forces; and
3. Increase the ability of foreign military and civilian personnel to instill and maintain democratic values and protect internationally recognized human rights in their own government and military. ${ }^{3}$

The courses that are funded through IMET range from training courses that last for a couple of weeks, to the longer education programs at U.S. war and staff colleges that last

\footnotetext{
Derek S. Reveron, Exporting Security: International Engagement, Security Cooperation, and the Changing Face of the U.S. Military (Washington, DC: Georgetown University Press, 2010), 109.

2 U.S. Department of Defense and U.S. Department of State Joint Report to Congress, Foreign Military Training, Fiscal Years 2012 and 2013, vol. I (Washington, DC, 2011), II-2. II-2.

U.S. Department of Defense and U.S. Department of State, Foreign Military Training, Fiscal Years 2012 and 2013, pp. II-1,
} 
one year. Overall IMET is not very expensive, comprising about 0.2 percent of the budget of the State Department. ${ }^{4}$ In 2012, the cost of IMET was roughly $\$ 106.1$ million dollars, but this relatively small amount of money funded over 6,000 foreign students from 135 allied and partner nations to attend courses. ${ }^{5}$ The participation in IMET programs by officials from Yemen, as described below, provides an illustration of the different types of programs that are funded and the various backgrounds of officials who attend.

In fiscal year 2012, 376 Yemenis attended IMET funded courses for a total cost of \$2.38 million dollars. The courses that they attended varied and included: (1) U.S. taught courses in Sana'a, Yemen; (2) NATO and/or U.S. taught courses in third-party countries including Bulgaria, Germany, and Italy; and (3) U.S. taught courses at a variety of locations within the United States. Yemeni nationals who attended these courses came from the Ministries of Defense, Interior, and Foreign Affairs as well as personnel from the active duty military and other security related organizations such as the police. In terms of short training courses, one example is the attendance by two soldiers at the two-week civil-military relations course that is taught at the U.S. Naval Post-Graduate School in Monterey, California. In terms of moderate length courses lasting several months, an example would be attendance by government and military personnel in English language training courses at Lackland Air Force Base in San Antonio, Texas. In terms of the longer duration courses at U.S. military war and staff colleges, there were six officers and officials funded in 2012. Table 1 (below) shows which elite U.S. professional military institutes hosted the exchange students from Yemen and the organizations that these officials came from within the government of Yemen.

Table 1- Example of Attendance at U.S. War and Staff Colleges, FY 2012 Yemen

\begin{tabular}{l|l|l}
\hline U.S. Location & Student's Home Organization & Length of Course \\
\hline National Defense University & National Security Bureau & 18 Jul 2011 - 7 Jun 2012 \\
\hline Naval Command College & Yemen Coast Guard & 27 Jul 2011 - 15 Jun 2012 \\
\hline Naval Staff College & Yemen Coast Guard & 27 Jul 2011 - 15 Jun 2012 \\
\hline Naval Staff College & Yemen Navy & 27 Jul 2011 - 15 Jun 2012 \\
\hline Army War College & Republican Guards & 2 Aug 2011 - 11 Jun 2012 \\
\hline Command and General Staff College & Department of Military Intelligence & 14 Feb 2012 - 16 Dec 2012 \\
\hline
\end{tabular}

Source: U.S. Department of Defense and U.S. Department of State, Foreign Military Training, Fiscal Years 2012 and 2013, vol. I (Washington, DC, 2011), Sect. IV-IV, 51-55.

In addition to attending the war or staff college as shown in Table 1, it is likely that these officers and officials also attended a month-long preparatory course at their U.S. war or staff college prior to the start of the formal course; and previous to that, some may have attended one of the IMET English language courses.

As the U.S. government's centerpiece program IMET provides grant funding for countries that would not otherwise be able to send their personnel to participate in U.S.

4 Based on FY 2012 State Department budget of $\$ 50.9$ billion.

5 U.S. Department of Defense and U.S. Department of State, Foreign Military Training, Fiscal Years 2012 and 2013, pp. II-1, 
military training and education courses. Funding for military exchanges in general comes from a variety of sources making it difficult to use IMET appropriations as a way to measure a country's participation. The U.S. Congress appropriates grant funding for IMET as part of Foreign Military Financing (FMF). The United States also sells slots to its schools to foreign governments as part of Foreign Military Sales (FMS). The type of school varies widely from yearlong courses of study at the prestigious U.S. war colleges to shorter technical training courses on maintenance and operation of equipment purchased from the United States.

While there are several ways for foreign governments to fund study programs at U.S. elite military schools for their personnel, this does not mean that there are an unlimited number of slots. The State Department allocates slots (with the approval of Congress). There is generally only one slot per country at any one war or staff college in any one class. The U.S. government's goal is to have a wide distribution of countries represented. For example, the current class (graduating in 2015) at the U.S. Army War College includes 79 foreign officers representing 73 different countries: Afghanistan, Albania, Armenia, Austria, Australia, Bangladesh, Botswana, Brazil, Bulgaria, Burundi, Canada, Chile, Colombia, Democratic Republic of Congo, Croatia, Czech Republic, Denmark, Djibouti, Egypt, El Salvador, Estonia, Ethiopia, France, Georgia, Germany, Ghana, Hungary, India, Indonesia, Israel, Italy, Japan, Jordan, Kazakhstan, Kenya, Korea, Kuwait, Lebanon, Libya, Lithuania, Macedonia, Malaysia, Mexico, Mongolia, Morocco, Mozambique, Nepal, Netherlands, New Zealand, Nigeria, Norway, Pakistan, Peru, Philippines, Poland, Romania, Saudi Arabia, Senegal, Serbia, South Africa, Spain, Sweden, Switzerland, Taiwan, Tanzania, Togo, Tunisia, Turkey, Uganda, Ukraine, United Arab Emirates, United Kingdom, and Yemen. ${ }^{6}$ In terms of the selection of specific persons for the military exchanges, the U.S. embassies play a role in vetting participants, but the exchange students are chosen by their home countries to fill the slots allocated to that country. The exchange officers constitute a significant portion of the student bodies at the war and staff colleges. Percentages vary by school with 10-20 percent of the students being foreign military officers.

The U.S. Army's schools provide a useful illustration of the stature and influence of the international graduates of U.S. war and staff colleges. The U.S. Army's Command and General Staff College (CGSC) has the longest running program, hosting international officers since $1894 .^{7}$ As of 2014, more than 7,500 foreign military officers had graduated from CGSC. Of these, more than half had obtained the rank of general and 253 officers from 70 different countries had become chief of their military, commander of a multinational force, or head of state. Notably, as of April 2014, 28 CGSC international graduates had achieved the highest position in their country as head of state. ${ }^{8}$ Former Indonesian President Susilo Bambang Yudhoyono is an excellent example. Yudhoyono, a former military officer, was a 1991 graduate of CGSC. In 2005, he became the first sitting head of state to be inducted into the CGSC's international alumni hall of fame. Yudhoyono was recognized internationally for his role in bringing peaceful democratic transition to Indonesia.

At the senior-level school, the U.S. Army War College graduated its first international

6 U.S. Army War College Community Banner, "International fellows, US students honored by The Army's 'Old Guard'," August 8, 2014, accessed September 14, 2014, http://www.carlisle.army.mil/banner/article.cfm?id=3602.

7 John Reichley, International Officers: A Century of Participation at the United States Army Command and General Staff College (Fort Leavenworth, KS: US Army Command and General Staff College, 1994).

8 "Three to be inducted into Fort LV's International Hall of Fame," Leavenworth Times, April 24, 2014, accessed September 8, 2014, http://www.leavenworthtimes.com/article/20140424/News/140429558. 
students in 1978 and approximately 10 percent of all its international alumni have become Army Chief or Defense Chief in their country. ${ }^{9}$ It is impressive to note that in spring 2013, twenty international alumni from this one school alone were serving as Army or Defense Chief in their countries - these countries included Germany, Korea, India, Canada, Denmark, Uganda, Norway, Egypt, Italy, Philippines, Lithuania, New Zealand, Oman, Australia, Hungary, Estonia, Georgia, and the Netherlands. ${ }^{10}$ The current class of 2015 -- with 79 foreign officers representing 73 different countries -- is the largest international class ever at the Army War College. ${ }^{11}$ The above statistics on distinguished foreign graduates are consistent across all of the war and staff colleges with international graduates going on to hold very important political and military positions in their home countries. In fact, this is to be expected because both U.S. and foreign students are chosen for attendance because they are the rising elite-level leaders in their countries.

An important component of the exchange experience is the opportunity for the participants to bring their family along to live in the United States, and the majority of the participants do so. ${ }^{12}$ Each military school has formal programs and has organized volunteers from the local area to help the foreign participants and their families settle into life in their local U.S. communities. Local area civilian and military volunteers help the foreign participants and their families with such tasks as enrolling children in schools, offering volunteer-led English language classes for spouses and children, and setting up social events for the entire family. Since each school runs its own educational exchange program, there is some variation in how these volunteer programs are organized, but overall the experience for the officers is similar.

\section{The Nature of the Exchange Experience at U.S. War and Staff Colleges}

The U.S. war and staff college programs are one subset of the enormous network of educational opportunities available for foreign personnel in U.S. military schools, but they are a very important subset because they educate rising military leaders and defense-related personnel who are most likely to become elite-level decision-makers in their home countries. The educational experience at the war and staff colleges is intensive for both U.S. officers and for their international counterparts. The curriculum includes eight hours of classroom instruction each day as well as a number of activities in off-duty time. The organization of the students is an important way that the schools build esprit de corps, trust between officers, professional networks, and lifelong friendships. The students are broken into seminar groups of roughly 14-20 members (depending on the school). Each seminar group has its own room and the group stays together for 6 months and then the members are re-shuffled into a new seminar group for the second half of the course. For each course, a variety of instructors come into the seminar room and teach the group, but the group stays together. This is a significant difference from civilian university exchanges in which students are in a different room with different classmates for each class. Thus, the military students spend the majority of each day with the same people. Most of the military students remain in touch with their first seminar group as their primary set of friendships formed at the school. They also stay in touch with their seminar-mates after graduation as their primary (although certainly not

\footnotetext{
9 John Burbank, "German, Dutch Army Chiefs Inducted into Hall of Fame," The Torch (Spring 2013): 25.

10 Burbank, "German, Dutch Army Chiefs Inducted," 25.

11 Army War College Community Banner, "International fellows, US students honored by The Army's 'Old Guard'".

12 At the expense of the officer, not the U.S. government.
} 
exclusive) professional networking group.

Seminar composition represents the diversity within the school. For example, at the Air Command and Staff College a seminar group of 14 students will typically include 1-2 women officers; 1-2 officers from a sister service, the national guard, the reserves, or DoD civil service; 2 foreign officers (each from a different country); and the rest Air Force officers. The seminar groups spend the day together. The manner of instruction is generally first to attend a large lecture combining all students followed by seminar discussions. In the lecture hall the seminar group sits together. There may also be simulations and exercises where the seminar group will work as a team to solve a problem. On some afternoons there will be intramural sports and the seminar groups will compete with each other. In each seminar group the senior U.S. officer will be designated the seminar leader and other seminar members will be assigned to organize various tasks, such as study groups, sports competitions or social gatherings. It is common for the seminar group to have at least one social event (such as: barbecue, pool party, golf outing, musical concert, birthday party, or study group) each week during their off-duty hours and many of these events will include the spouses and children of the officers. The U.S. spouses also organize outings and events for fellow U.S. and international spouses and their children during the time that the officers are in school.

Like many other educational exchange programs, the students at U.S. war and staff colleges learn useful information in the classroom. Subject areas include military history, strategic theory, national security organization, international relations, military doctrine, civil-military relationships, interagency cooperation, resource management, military operational planning, and leadership. These subjects help provide a common frame of reference both intellectually and operationally for both the U.S. and foreign students. The Field Studies Program is an additional requirement for foreign students. The explicit goal of this program is to expose the foreign students "to the U.S. way of life, including regard for democratic values, respect for individual civil and human rights, and belief in the rule of law." ${ }^{13}$ It includes classroom instruction as well as hands-on activities. Field trips are one of the highlights of the program. The field trips are a fun way to expose participants to U.S. institutions, society, and culture. Trips sponsored by U.S. military war and staff colleges are quite varied. Some examples of past visits include traveling to Washington, DC to meet with U.S. Congressmen, attending local town council meetings, visiting REI and Starbucks headquarters in Seattle, visiting local correctional facilities (i.e. prisons), and riding horses at a dude ranch in Montana. All of these varied activities that are part of the Field Studies Program help to introduce participants to different aspects of U.S. culture, politics, and institutions. Importantly, they also help to build comradery and friendships amongst the military officers.

In addition to knowledge acquired in lectures, seminars, and hands-on exercises, new perspectives and friendships are also gained through the intensive social integration and social interaction with U.S. military personnel both in and out of the classroom and with ordinary U.S. people in local communities. These types of social activities nurture positive perspectives of the United States and in the longer term help the United States to achieve foreign policy goals when its goals and preferences are shared across national boundaries. Indeed, the military officers are similar to exchange participants the world over in that they come away with more knowledge about their host country, warm feelings for the people who 
were their hosts, and a desire to maintain these friendships and professional connections for many years to come. ${ }^{14}$

Sponsors programs are an important part of the exchange experience for the foreign officer and his/her family. Each foreign officer is assigned at least one sponsor from the military base or local community. The Army Command and General Staff College (located in Leavenworth, Kansas) assigns each foreign student three sponsors: one from the local military community, one from the local town of Leavenworth, and one from the greater Kansas City metropolitan area. The sponsor programs are run by volunteers and receive no U.S. government funding. While some sponsors are associated with the U.S. military, others have no immediate connection, but are ordinary people in the local communities. Some sponsors have volunteered for numerous years, even decades, to work with the foreign officers and their families. They are a key component in helping the exchange participants and their families navigate U.S. society and culture. The sponsors help the exchange officers when they first arrive in the United States to settle into the local community. They help the officer and his/her family for their entire stay. The sponsors invite the exchange officers and their families to their homes for events and holidays such as Thanksgiving and Christmas celebrations. They may also go to events such as state fairs or local concerts together. The sponsor programs support all three goals of the officer's attendance at a war or staff college from providing information on U.S. society and culture to building a positive perspective of the United States, its citizens and way of life. An observation made by a foreign exchange officer from Asia-Pacific illustrates. When asked to describe his best experiences during his foreign exchange program, the officer said that his best experience was: "Our family could meet the wonderful sponsors. We spent much time with them; they were like our parents in the USA. We could learn how Americans think, feel, and also we could share common values with them." $" 15$

\section{Lessons Learned from the Military Educational Exchange Programs}

The military exchanges at the U.S. war and staff colleges are particularly successful in building trust, friendships, and intercultural understanding among participants from widely diverse backgrounds because they emphasize integration and intense social interaction as a mandatory part of the program for all students, both U.S. and non-U.S. There are at least seven lessons that can be learned from the exchange experience at U.S. war and staff colleges both for international exchange program design and for when we consider the role and functions of exchange programs as a component of foreign policy.

First, the military exchange programs at the military schools are effective in socially constructing a U.S. centric network of military professionals across the globe because they emphasize social and professional interactions. After graduation, members of the network are linked together through common experiences and shared expertise. As described above, the military educational exchanges mix and mingle participants from different countries. As a military exchange participant, there is no escaping professional and social interaction, as for example might happen at civilian universities where civilian students might socialize only with others who speak the same home language, choose classes with compatriots, sit

14 Carol Atkinson, Military Soft Power: Public Diplomacy Through Military Educational Exchange Programs (Lanham, MD: Rowman \& Littlefield, 2014).

15 Atkinson, Military Soft Power, 111. 
together with compatriots in classes, or live in isolated enclaves with others from the same home country.

The social activities and interactions at the military schools foster professional and social networks amongst participants and provide a personal support system within the school that results in a professional network of friends and colleagues across the globe. With modern communication systems, it is now easier than ever to keep in contact across national borders. These networks function as transnational channels of information of all sorts, from continuing professional development to keeping up with friends. Because the officers in these networks are considered experts in their field and occupy, or are likely to occupy, important military positions, they often have contacts in important military and political institutions. In this sense they form an epistemic community or "network of professionals with recognized expertise and competence in a particular domain and an authoritative claim to policy-relevant knowledge within that domain." 16 According to Peter Haas, these types of professional networks are repositories of specialized knowledge that state leaders may draw upon in order to identify salient issues, define national interests, and formulate policies. ${ }^{17}$ In the case of the alumni of U.S. war and staff colleges, the officers share expertise as military professionals and are likely to share common frames of references learned during their U.S. military exchange program. Contacts within this professional network have been useful, for example, in facilitating U.S. operational deployments. The relationships built during military exchanges have helped the U.S. military to gain access to forward operating bases and to preposition weapon systems in a number of Middle Eastern countries. ${ }^{18}$

The second lesson for exchange program design is an assumed, but frequently unexamined, aspect of exchange programs: whether the participant returns home after his/her program is finished. If the goal of exchange programs is to build cross-cultural understanding between countries, then participants should be those seeking an exchange experience rather than immigration. Exchange participants that "go native" certainly demonstrate the powerful socializing impacts of travel and study abroad, but this behavior may defeat the core purpose of an exchange program to expand cultural awareness and cross-cultural competence between countries. Unlike many other types of exchanges, the military officers must return home; and when they do, they bring with them the knowledge, perceptions, and friendships built while abroad. Civilian exchange participants at U.S. universities often seek to remain in the United States; however, for the military exchange participants there is no such possibility. For the military exchange student, whatever is learned in and about the United States travels back to the student's home country; "going native" is not an option.

A third lesson is related to the first two lessons and concerns the wider impacts that may occur as the exchange participant advances in his/her career and more compatriots return home with similar education and experiences. As more and more people from a country participate in U.S. hosted military educational exchange programs, the network of military exchange graduates in any one country will grow more influential. The influence of graduates grows as more and more of them enter into elite leadership positions and can design and implement national-level policies relying on fellow graduates for support. The network within

${ }_{16}$ Peter M. Haas, "Introduction: Epistemic Communities and International Policy Coordination," International Organization 46, no.1 (1992), 3.

17 Haas, "Epistemic Communities," 2-3.

18 Derek S. Reveron, "Weak States and Security Assistance," PRISM 1, no.3 (June 2010), 30. 
any one country is important in helping senior officers to update, improve, or reform military doctrine and military operations by providing a support system of similarly trained colleagues who are likely to share the same goals. Thus, within the wider epistemic community there are also these smaller country-specific cohorts that can influence policy, particularly as the cohort grows in numbers. When asked about these country-specific connections, over $97 \%$ of foreign students at U.S. war and staff colleges said that they knew someone from their home country who had graduated in a previous class; and $67 \%$ knew of a previous graduate in their home country who had a "very important" military job. ${ }^{19}$

A fourth lesson for the design of international exchange programs is the importance of family in longer duration programs. At the military schools, the exchange participant's entire family is welcomed and socially integrated within the local military and civilian communities through specific activities organized by the schools and by the U.S. military officers and their families. Thus, intercultural understanding and international friendships are built not only by the officer, but also by his/her entire family. Both spouses and children also come away with increased knowledge about the United States, new U.S. friends, a better ability to speak English, and a more positive view of the United States. Children expand the types of social interactions that the officers and their spouses experience, involving the entire family in activities that the exchange officer might not otherwise have such as becoming involved in his/her children's schools, hobbies, and sporting events. These activities help widen the entire family's circle of friendships. Spouses are also an important part of the entire socialization experience. They are a trusted person with whom to share the excitement of new adventures and who provide support and commiseration in case of problems. The opportunity to be accompanied by family members on an exchange is an underappreciated and under studied factor that can greatly improve the foreign exchange student's experiences.

The fifth lesson relates to accomplishing one of the explicit foreign policy goals of the military exchange programs to "increase the ability of foreign military and civilian personnel to instill and maintain democratic values and protect internationally recognized human rights in their own government and military." ${ }^{20}$ Statistical evidence shows that over the longer term countries that participated in the exchange programs at U.S. military war and staff colleges were more than twice as likely to succeed in their efforts to transition to more liberal/ democratic forms of governance than countries that did not participate. ${ }^{21}$ During their year in the United States, participants from less-than-democratic countries were exposed to everyday life under democratic governance. As students and heads of their families, the foreign officers must navigate their local U.S. communities in which their schools reside. And over the course of a year they are exposed to democratic governance, both good aspects and bad aspects, as citizens of the United States experience it on a daily basis. While coursework might provide education on, for example, legal systems, the time spent off-duty living under mature systems of rule of law where policeman exercise authority in a system where all citizens are equal under the law exposes participants from less-than-democratic countries to real life functioning of rule of law. As an illustration, one exchange officer from a nondemocratic country remarked that one of the best aspects of the United States was that it was "a society that holds everyone

\footnotetext{
19 Atkinson, Military Soft Power, 99-100.

20 U.S. Department of Defense and U.S. Department of State, Foreign Military Training, Fiscal Years 2012 and 2013, II-1, II-2.

21 Atkinson, Military Soft Power, 143-147.
} 
accountable, responsible but at the same time everyone has rights and privileges that he enjoys. ${ }^{.22}$ Both book learning and experiential learning provide useful information for those seeking to build and consolidate democratic norms and institutions in their own countries.

The sixth lesson focuses on how the potential to attend a military exchange program can have a wider effect beyond those who are chosen to participate. My research identified that for countries that are in the process of developing democratic governance, the possibility to attend a school abroad, particularly in the United States, provides motivation to develop the skills that are prerequisites for attendance such as fluency in the English language. An aspiring participant may choose to spend several years teaching themselves English through books, hiring an English tutor, or going to evening classes in English in order that they might have the opportunity to participate in U.S. IMET funded schools in the United States. ${ }^{23}$ This phenomenon has been noted in countries transitioning to more democratic institutions, thus it might also help in democratization processes because speaking and reading English opens up new sources of information even if the person never goes abroad.

The seventh lesson concerns how educational exchanges in general help to advance the interests and influence of the hosting country through soft power. Soft power is the ability to achieve goals by persuading or socializing others to adopt your own perspectives and preferences. This effect is particularly noteworthy in the case of the military educational exchanges because military organizations are usually associated with the exercise of hard power. The exchanges are one way that the U.S. military extends its influence through ideas, beliefs, and norms. According to Joseph Nye in his classic work on the topic, soft power can be built through agentive strategies and structural effects. The military exchanges encompass both mechanisms. Agentive strategies are programs and actions of government agents. ${ }^{24}$ As discussed above, the military schools' officials (instructors, program officers, U.S. volunteers, and U.S. sponsors) play a key role shaping the perspectives of the foreign officers. Soft power can also be gained through what Nye called structural effects, meaning setting an example that others wish to emulate. ${ }^{25}$ According to Nye, structural effects are gained and soft power accrues to the entity whose culture is pleasing to others; whose values are attractive and consistently practiced; and whose policies are seen as inclusive and legitimate. ${ }^{26}$ The military exchanges are designed to show these aspects of life in the United States. It is expected that the military exchange participant, by living and interacting on a daily basis with U.S. people, is likely to come away from his/her experience with a more positive view of the United States. This is indeed what happens in the case of the military exchanges. When asked to reflect upon the most important thing they learned about the United States during their time at a U.S. war or staff college, international participants identify aspects of how Americans think and act, how U.S. democracy works, and different aspects about U.S. lifestyles and culture as the most important things that they learned during their exchange. ${ }^{27}$ While not all observations are positive, the overall impact is positive with both U.S. and foreign graduates calling their year at the war or staff college "one of the best years" of their lives. ${ }^{28}$

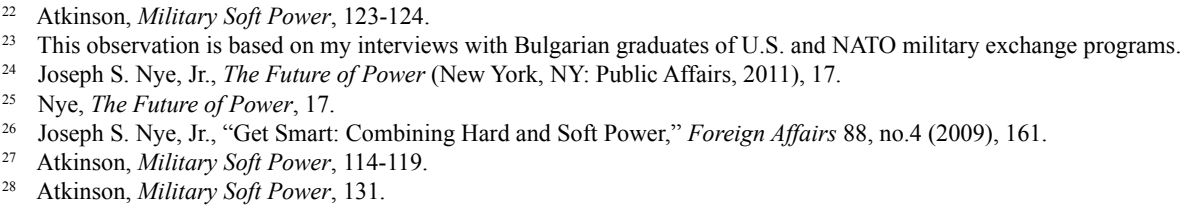




\section{Conclusion}

Military educational exchange programs at U.S. war and staff colleges are structured to build trust, intercultural understanding, and a shared frame of reference among U.S. officers and their international counterparts. Because the programs are successful in doing this, the U.S. military has benefited from increased understanding, cross-national interoperability, and defense cooperation with militaries around the world. Additionally, the U.S. government has been able to support governments transitioning to more democratic forms of governance.

Three important aspects are worth reiterating here. First, the military exchanges at the U.S. war and staff colleges are particularly successful in accomplishing their goals because they emphasize integration and intense social interaction as a mandatory part of the program for all students, both U.S. and foreign. Second, having one's family along on the exchange enhances an exchange participant's overall positive experience. Sharing the trials and successes of living abroad with one's spouse and children opens up new opportunities for interaction and lessens the effects of culture shock. The entire family builds memories and friendships that they will share together as a family once the year abroad is over. Third, an important aspect of international educational exchange program design is the incorporation of mandatory activities that enhance cultural and social learning. For the military officers, the Field Studies Program and sponsorship programs perform a key role in building a positive exchange experience because these programs introduce the exchange participant to opportunities, institutions, and experiences that they might not otherwise have on their own. Additionally, the volunteer-led sponsor programs help to ameliorate the stresses of new situations and lessen culture shock by providing an experienced personal guide to the local community. These aspects of the military exchange programs could also be implemented in other types of exchanges to improve their effectiveness in building friendships and professional networks that incorporate members from very diverse cultural, social, and political backgrounds.

\section{Bibliography}

Atkinson, Carol. Military Soft Power: Public Diplomacy through Military Educational Exchange Programs. Lanham, MD: Rowman \& Littlefield, 2014.

Burbank, John. "German, Dutch Army Chiefs Inducted into Hall of Fame.” The Torch (Spring 2013).

Haas, Peter M. "Introduction: Epistemic Communities and International Policy Coordination." International Organization 46, no.1 (1992): 1-35.

Nye, Jr., Joseph S. The Future of Power. New York, NY: Public Affairs, 2011.

—. "Get Smart: Combining Hard and Soft Power." Foreign Affairs 88, no.4 (2009): 160-63.

Reichley, John. International Officers: A Century of Participation at the United States Army Command and General Staff College. Fort Leavenworth, KS: US Army Command and General Staff College, 1994.

Reveron, Derek S. Exporting Security: International Engagement, Security Cooperation, and the Changing Face of the U.S. Military. Washington, DC: Georgetown University Press, 2010.

. "Weak States and Security Assistance." PRISM 1, no.3 (June 2010).

U.S. Army War College Community Banner. "International fellows, US students honored by The Army's 'Old Guard'." August 8, 2014. Accessed September 14, 2014. http://www.carlisle.army.mil/banner/article. $\mathrm{cfm} ? \mathrm{id}=3602$.

U.S. Department of Defense and U.S. Department of State Joint Report to Congress. Foreign Military Training, Fiscal Years 2012 and 2013, Vol. I. Washington, DC, 2011. 